\title{
Impact of Lysinibacillus macroides, a potential plant growth promoting rhizobacteria on growth, yield and nutritional value of tomato plant (Solanum lycopersicum L. F1 hybrid Sachriya)
}

\author{
Jyolsna K S, Bharathi N, Riyaz Ali L \& Paari K* \\ Department of Life Sciences, CHRIST (Deemed to be University), Bengaluru, Karnataka, 560 292, India \\ *Email: paari.ka@christuniversity.in
}

\section{ARTICLE HISTORY}

Received: 01 January 2021

Accepted: 10 March 2021

Published: 01 April 2021

\section{KEYWORDS}

Lysinibacillus macroides

Pseudomonas fluorescens

Solanum lycopersicum

Compost

Nitrogen fixing

PGPR

\section{ABSTRACT}

Plant growth promoting bacteria enhance the growth in plants by solubilizing insoluble minerals, producing phytohormones and by secreting enzymes that resist pathogen attack. The present study was aimed at identifying the potential of Lysinibacillus macroides isolated from pea plant possessing rich microbial rhizobiome diversity in promoting the growth of tomato plant (Solanum lycopersicum L.). Potential of L. macroides in the promotion of S. lycopersicum L. growth by increased shoot length, terminal leaf length and breadth was assessed. Anatomical sectioning of stem and root revealed no varied cellular pattern indicating that the supplemented bioculture is not toxic to S. lycopersicum. Plantlets treated with L. macroides along with organic compost showed an increased total phenol content $(17.58 \pm 0.4 \mathrm{mg} / \mathrm{gm})$ compared to control samples $(12.44 \pm 0.41 \mathrm{mg} / \mathrm{g})$. Carbohydrate content was noticed to be around 1.3 folds higher in the L. macroides plus compost mixture supplemented slots compared to control sample. Significant increase in shoot length was evident in the $L$. macroides plus compost supplied slots $(23.4 \pm 2.7 \mathrm{~cm})$. Plant growth promoting properties might be due to the nitrogen fixing activity of the bacteria which enrich the soil composition along with the nutrients supplied by the organic compost. Rich microbial rhizobiome diversity in pea plant and the usage of $L$. macroides from a non-conventional source improves the diversity of the available PGPR for agricultural practices. Further research is needed to detect the mechanism of growth promotion and to explore the plant microbe interaction pathway.

\section{Introduction}

With the expectancy of the global population rising to 9 billion by 2040 , there is a major threat faced by the developing countries to address the problems associated with crop production (1). Meeting the demand for high yielding crop varieties with enhanced nutritional content is the need of the $\mathrm{hr}$ for agriculture agencies. Better quality and improved productivity of crop plants is possible by replacing the lost nutrients in the cultivable land (2). Solanum lycopersicum, one of the most cultivated fruits worldwide for its nutrients such as lycopene, $\beta$ carotene, flavonoids and vitamin $\mathrm{C}$ are known to have high market value for their antioxidant properties (3). It is used in various cuisines of the world and is also used as a model plant for fleshy fruited dicots (4).
Farming practices using chemical fertilizers for long tenure decreases the soil fertility and agricultural productivity thereby affecting the natural process of nitrogen fixation in the soil $(5,6)$. As an alternative, organic fertilizers and biofertilizers provide an ecofriendly approach by improving nutrient uptake, water absorption, water retainability, atmospheric nitrogen fixation, phosphate solubilisation $(7,8)$. Plant benefiting microorganisms grouped as Plant Growth Promoting Rhizobacteria (PGPR) offer a wide range of benefits by colonising the root and promote plant growth by improving the accessibility to bionutrients, solubilisation of inorganic phosphate and by limiting plant pathogens (3). PGPR confers growth benefits to plants either directly or indirectly (9). PGPR act directly by aiding nitrogen fixation, enhancing iron uptake, secreting organic acids, solubilizing insoluble

(C) Jyolsna et al. (2021). This is an open-access article distributed under the terms of the Creative Commons Attribution License, which permits unrestricted use, distribution and reproduction in any medium, provided the original author and source are credited (https://creativecommons.org/licenses/by/4.0/).

To cite this article: Jyolsna K.S, Bharathi.N, Ali.L R, Paari KA . Impact of Lysinibacillus macroides, a potential plant growth promoting rhizobacteria on growth, yield and nutritional value of tomato Plant (Solanum lycopersicum L. F1 hybrid Sachriya). Plant Science Today. 2021;8(2):365-372. https://doi.org/10.14719/pst.2021.8.2.1082 
phosphate and by producing phytohormones (10-12). Indirect mode of action is by producing protease kind of enzymes that resist fungal attack and chemicals like hydrogen cyanide (HCN) that inhibit pathogen growth $(12,13,14)$. Several diverse genera of microbes are employed as PGPR including Bacillus, Pseudomonas, Arthrobacter, Paenibacillus and Lysinibacillus $(15,16)$. Bacillus cereus and Klebsiella variicola isolated from the rhizospheric region of tomato capable of secreting phytohormones such as GA3, IAA and kinetin enhanced mineral uptake and upregulated chlorophyll synthesis (17). Lysinibacillus reported for its ability to tolerate metal has been tested for its efficacy to promote plant growth promotion in polluted environment (18). $L$. macrolides, supplemented individually or as a consortium culture conferred antimicrobial activity against plant pathogen Xanthomonas campestris, causative bacterium that is known to cause black rot of cabbage (19). Total nitrogen content in the soil can be enhanced by L. macroides by its ability to fix atmospheric nitrogen and decompose organic matter (20). Nitrfying bacteria convert the atmospheric nitrogen $\left(\mathrm{N}_{2}\right)$ into organic nitrogen which can be utilized by plants. Certain bacteria like Providencia spp. enhance plant growth by secreting phytohormones such as indole acetic acid $(21,22)$. Microbe and its secretory products are widely employed in disease inhibition and shelf life extension. Artificial introduction of microbial antagonists found to be more efficient in disease control and exhibited limited pathogen attack (23, 24). A combination of technological advances in agricultural farming comprising both biofertilizers and postharvest treatment will ensure better yield in agriculture (25). Unexplored microbial community from the pea plant cultivated in the agricultural ecosystem result in identification of novel diverse rhizosphere microbiomes for agricultural practices. Our study is focused on identifying a novel plant growth promoting bacteria from the rhizosphere of pea plant and their efficacy in enhancing the growth of S. lycopersicum L. was evaluated.

\section{Materials and Methods}

\section{Isolation and Identification of PGPR from Pisum sativum}

Rhizospheric soil sample was collected from $P$. sativum propagated in an agricultural ecosystem near IIHR (Indian Institute of Horticultural Sciences), Bengaluru, India. The sample (1 gm) was suspended in $10 \mathrm{ml}$ of sterile water and was serially diluted. The diluted sample was spread plated onto yeast extract mannitol agar (YEMA) and incubated for $24 \mathrm{hrs}$ at 37 ${ }^{\circ} \mathrm{C}$ (22). The isolates obtained were screened for its nitrogen fixing, phosphate and zinc solubilizing ability (16, 26, 27). Culture was biochemically characterised using Gram's staining, IMViC tests and screened for its ability to produce ammonia, hydrogen cyanide and siderophores $(28,29)$. The $16 \mathrm{~S}$ rDNA gene from the isolated genomic DNA was amplified using 27F: 5'-AGAGTTTGATCCTGGCTCAG-3' and 1492R: 5'-GGTTACCTTGTTACGACTT-3' primers. The resulting amplicon was purified and sequenced using BDT v3.1 Cycle sequencing kit on ABI 3730xl Genetic Analyzer and the obtained sequence was compared with the homology search tool BLAST in NCBI genbank database for species identification. A phylogenetic tree was constructed using Mega-X version 10.2.4 using the maximum likelihood method based on the Kimura 2-parameter model (30-32).

\section{Application of the isolated PGPR for growth enhancement}

\section{Experimental design}

A total of five treatment groups along with a control were designed for the application study (Table. 1). Pseudomonas fluorescens procured from the culture collection center, GKVK Bangalore, India served as a positive control. P. fluorescens is a PGPR well known for its ability to fix atmospheric nitrogen, production of plant growth promoting compounds (IAA) and production of antimicrobial agents such as bacteriocins, antibiotics, and siderophores. Compost was prepared by packing multiple layers of food and vegetable waste over a layer of crushed dried leaves in a compost pit dug to one feet depth. The leaves and waste were laid in 1:1 ratio and the pit was covered with soil and charcoal to facilitate composting. After 30 days, the contents from the pit were mixed with dry cow dung and were utilized as compost.

\section{Seed germination}

Seeds of tomato plant (Solanum lycopersicum F1 hybrid Sachriya) were incubated for $1 \mathrm{hr}$ in a broth culture of $L$. macroides (8 Log CFU $/ \mathrm{ml}$ ) and $P$. fluorescens (8 Log CFU/ml) separately. Treated and control seeds were planted in a coco peat for germination. After 7 days, plantlets were transferred to pots (33). Inoculation of bioculture was initiated based on the concentration mentioned in Table 1 . The study was conducted for a period of thirty days. The bioculture (1ml) was supplemented to the plantlets at every two days interval and was maintained in a controlled environment in a polyhouse.

Table 1. Experimental combinations tested for plant growth promoting properties

\begin{tabular}{cll}
\hline $\begin{array}{c}\text { Sl. } \\
\text { no. }\end{array}$ & Experimental setup & Concentration \\
\hline 1. & Lysinibacillus macrolides & $(8 \mathrm{Log}$ CFU/ml) \\
\hline 2 & Pseudomonas fluorescens & $(8 \mathrm{Log}$ CFU $/ \mathrm{ml})$ \\
\hline 3. & Compost & $2 \%$ \\
\hline \multirow{2}{*}{ 4. } & Group supplemented with compost & $2 \%$ compost and (8 \\
& and Lysinibacillus macrolides & Log CFU/ml) culture \\
\hline \multirow{2}{*}{5.} & Group supplemented with compost & $2 \%$ compost and (8 \\
& and Pseudomonas fluorescens & Log CFU/ml) culture \\
\hline
\end{tabular}

\section{Growth and anatomy assessment}

The effects of the bioculture treatment on plant growth was analyzed for a period of 4 weeks by measuring the shoot length, leaf number, terminal leaf length and breadth every week (34). To check the effect of the PGPR on the vascular bundles and to determine whether the PGPR invades the root and stem, anatomical variations in control and the treatment group was carried out by analysing the transverse section of stem and root. Thin sections in 
triplicates were obtained and stained with safranin. The sections were observed under 150x magnification using a light microscope.

\section{Effect of L. macroides on the biochemical profile of S. lycopersicum}

\section{Total chlorophyll estimation}

Leaf sample (500 mg) obtained from each treatment group was homogenised using $10 \mathrm{ml}$ of $80 \%$ acetone and centrifuged at $10000 \mathrm{rpm}$ for $10 \mathrm{~min}$. at $4^{\circ} \mathrm{C}$. The supernatant was collected and the absorbance was measured at $645 \mathrm{~nm}$ and $663 \mathrm{~nm}$ and chlorophyll content was estimated (35).

\section{Protein estimation}

Protein content was estimated using the Bradford assay (36). Leaf samples (500 mg) from each treatment group were homogenised in $10 \mathrm{ml}(0.05 \mathrm{M})$ phosphate buffer and centrifuged at $10000 \mathrm{rpm}$ for 10 min. at $4{ }^{\circ} \mathrm{C}$. $0.1 \mathrm{ml}$ of supernatant was made up to $1 \mathrm{ml}$ using distilled water and $5 \mathrm{ml}$ of Bradford reagent was added to the test tubes including the blank (1ml of $\mathrm{d} . \mathrm{H}_{2} \mathrm{O}$ ) and the absorbance was measured at $595 \mathrm{~nm}$. A standard calibration curve was prepared using Bovine serum albumin (BSA).

\section{Carbohydrate estimation}

Carbohydrate was estimated using phenol-sulphuric acid method (37). Leaf sample (100 mg) was homogenised with $5 \mathrm{ml}$ of $2.5 \mathrm{~N} \mathrm{HCl}$ and was kept in a boiling water bath for duration of $3 \mathrm{hrs}$. After cooling, sample was neutralized by adding solid sodium carbonate powder till the effervescence ceased and centrifuged at $10000 \mathrm{rpm}$ for $10 \mathrm{~min}$. 200 $\mu \mathrm{l}$ of the supernatant was made up to $1 \mathrm{ml}$ with distilled water. $5 \mathrm{ml}$ of $96 \%$ sulphuric acid and $2 \%$ phenol were added in a cold water bath and the absorbance was measured at $490 \mathrm{~nm}$. A standard calibration curve was prepared using D-glucose.

\section{Determination of Antioxidant activity}

Antioxidant activity was estimated using DPPH scavenging assay (38). $0.1 \mathrm{gm}$ of powdered leaf samples were weighed and ground with $2 \mathrm{ml}$ methanol using mortar and pestle. The solution was transferred to eppendorf tubes and centrifuged at $10000 \mathrm{rpm}$ for $20 \mathrm{~min}$. $20 \mu \mathrm{l}(0.46 \mathrm{mg})$ of the extract was made up to $3 \mathrm{ml}$ with methanol. $1 \mathrm{ml}$ of DPPH $[0.004 \%(\mathrm{w} / \mathrm{v})]$ was added and incubated for $30 \mathrm{~min}$. in dark condition. Absorbance was measured at 513 $\mathrm{nm}$ and the antioxidant activity was calculated (38).

\section{Estimation of phytochemicals}

\section{Total phenolic content and tannin estimation (TPC)}

The total phenolic content (TPC) and tannin estimation was performed using the Folin-Ciocalteu assay (39). For TPC, $0.1 \mathrm{gm}$ of the powdered leaf sample was weighed and ground with $2 \mathrm{ml}$ of methanol in mortar and pestle. $50 \mu \mathrm{l}$ of the supernatant was made upto $3 \mathrm{ml}$ with distilled water. To the mixture, $0.5 \mathrm{ml}$ of the Folin-Ciocalteu reagent (1:1) was added followed by mixing with 2 $\mathrm{ml}$ of $20 \%$ sodium carbonate solution. Absorbance was measured at $638 \mathrm{~nm}$ after 3-5 min. incubation in a dark environment. Similarly for tannin estimation, $0.1 \mathrm{gm}$ of the powdered leaf sample was weighed and ground with $2 \mathrm{ml}$ of methanol in mortar and pestle. $50 \mu \mathrm{l}$ of the supernatant was made upto $1 \mathrm{ml}$ with distilled water. $0.5 \mathrm{ml}$ of the Folin-Ciocalteu reagent (1:9) was added followed by addition of $2 \mathrm{ml}$ of $20 \%$ sodium carbonate solution and the absorbance was recorded at $725 \mathrm{~nm}$ after 40 min. incubation in dark. The calibration curves for TPC and tannin were prepared using catechol and tannic acid respectively.

\section{Flavonoid estimation}

Flavonoid content was measured by modified aluminium chloride colorimetric method (40). $0.1 \mathrm{gm}$ of the powdered leaf sample was weighed and ground with $2 \mathrm{ml}$ of methanol in mortar and pestle. $50 \mu \mathrm{l}$ of the supernatant was mixed with $0.1 \mathrm{ml}$ of $10 \%$ aluminium chloride and $0.1 \mathrm{ml}$ of $1 \mathrm{M}$ potassium acetate. Absorbance at $415 \mathrm{~nm}$ was recorded after 40 min. incubation. A standard calibration curve was prepared using quercetin.

Note: Drying of leaves was carried out carefully without exposing the samples to direct sunlight in order to prevent loss of secondary metabolites. Absorbance for all values was measured using the Shimadzu UV-160A spectrophotometer.

\section{Statistical analysis}

All statistical analysis were carried out using online freeware ASTATSA and advanced tool pak VBA. One way Analysis of variance (ANOVA) was performed with Tukey HSD, Scheffé, Bonferroni and Holm comparisons and a p-value <0.05 was considered significant.

\section{Results and Discussion}

PGPR plays a crucial role in enriching the soil nutrients for better crop productivity. Our isolate, Lysinibacillus macroides exhibited ameliorative effects on growth and development of Solanum lycopersicum. Plant growth promoting bacteria exhibit positive effect in plants by enhancing nutrient availability and nutrient uptake. Few strains confer antagonistic effects by providing protection against plant pathogens and by tolerating abiotic stress factors. Various microorganisms namely Pseudomonas sp (41), Burkholderia ambifaria (42), Mesorhizobium sp. (43), Bacillus amyloliquefaciens (44), Pseudomonas pseudoalcaligenes and Bacillus pumilus (45) are utilised as PGPR for plant growth and for abiotic stress management. A study (42) demonstrated the utility of Herbaspirillum seropedicae, Gluconacetobacter diazotrophicus, Azospirillum brasilense and Burkholderia ambifaria for the growth of $S$. lycopersicum. The study not only assessed the role of PGPR in tomato plant growth but also revealed the host resistance to pathogens and their efficacy in nitrogen fixation (42). Results of this study analysed the effect of $L$. macroides infused compost made of vegetable and food waste on growth and yield of $S$. lycopersicum. 


\section{Isolation, screening and identification of PGPR}

The isolate obtained was biochemically characterised (Table. 2) and was identified as L. macroides (GENBANK accession number; MK517553) after performing a BLAST search with a maximum score of 1967 on a $99.36 \%$ query cover. A molecular phylogenetic tree was constructed using MEGA-X Version 10.2.4 by maximum likelihood method based on Kimura 2 parameter (Fig. 1).

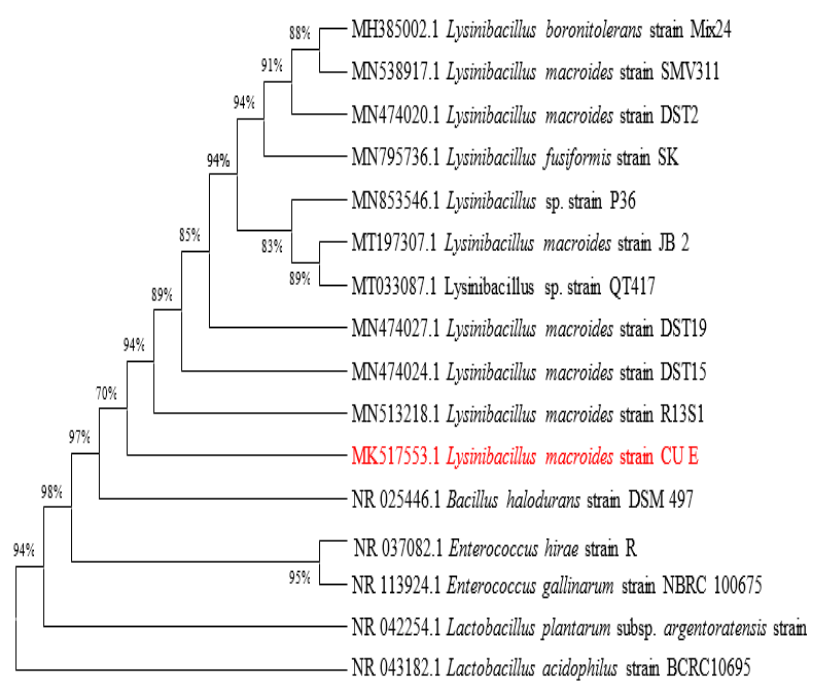

Fig. 1. Molecular phylogenetic analysis of PGPR based on the $16 \mathrm{~S}$ rRNA partial sequences. The optimal tree with the sum of branch length $=0.34754584$ is shown and was constructed using neighbor joining method. The evolutionary distances were computed using the Maximum Composite Likelihood method.There were a total of 1552 positions in the final dataset.Enterococcus sp. and Lactobacillus sp. were used as outgroups.

\section{Growth Assessment and anatomical examination of S. lycopersicum}

Growth enhancement in plants is attributed to good soil conditions that can be further enhanced by the application of organic, biofertilizers and PGPR (46). Compost supplemented with biofertilizer acts as an efficient soil amendment factor that facilitates water and mineral (nitrogen and phosphorus) uptake. Beneficial plant nutrients obtained from compost blended with nitrogen fixing bacteria and improve the availability of nitrogen sources for amino acid synthesis (47). In this study, growth measurements of Solanum lycopersicum was assessed for a span of thirty days and the study identified maximum shoot length and terminal leaf length in groups supplemented with L. macroides ( $\mathrm{p}<0.05$ ) (Fig. 2, Fig. 3 respectively). Increased stomatal conductance in PGPR supplied plants confers better water-use efficiency in PGPR supplemented plants (48). Terminal leaf breadth was highest in the group supplemented with compost only $(p<0.05)$ (Fig. 4). Growth enhancement in compost and L. macroides supplemented slots can be attributed for better nutrient enrichment in soil conditions. The effect of PGPR Pseudomonas fluorescens supplemented along with organic manure containing composted material of vegetable and fruit sources enhanced the growth and yield of maize plant (46).

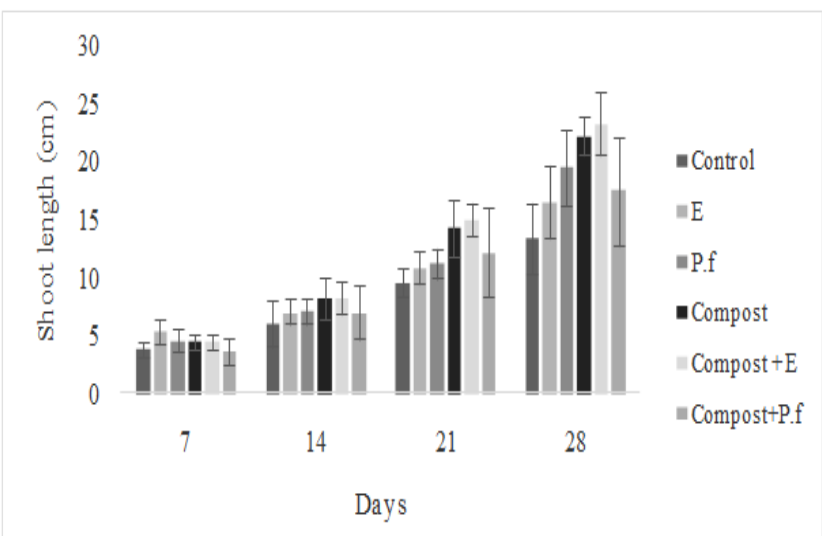

Fig. 2. Effect of culture Lysinibacillus macroides (E), Pseudomonas fluorescens ( $\mathrm{Pf})$, compost, compost + Lysinibacillus macroides (E) and compost + Pseudomonas fluorescens(Pf) along with control on shoot length. $(p<0.05){ }^{*}$ Data represented as standard deviation of triplicate values.

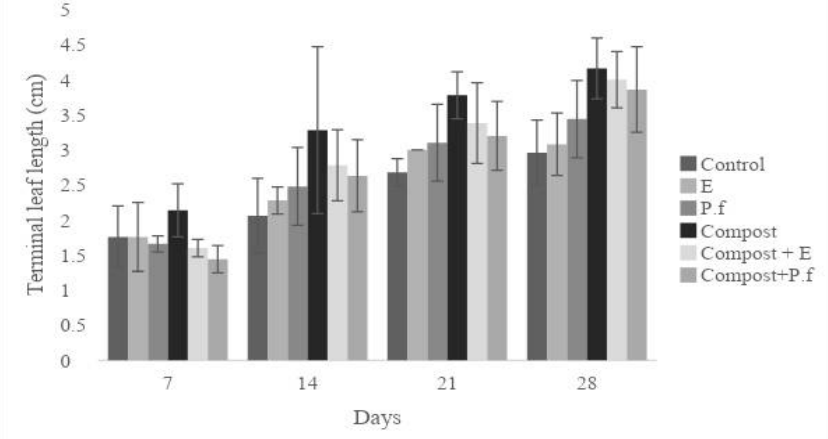

Fig. 3. Effect of culture Lysinibacillus macroides (E),Pseudomonas fluorescens (Pf), compost, compost + Lysinibacillus macroides (E) and compost + Pseudomonas fluorescens( $(\mathrm{Pf})$ along with control on terminal leaf length $(\mathrm{p}<0.05) *$ Data represented as standard deviation of triplicate values.

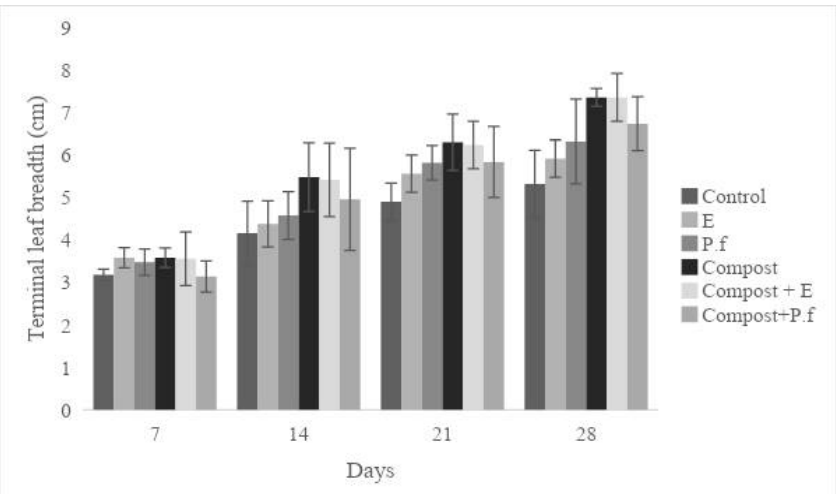

Fig. 4. Effect of culture Lysinibacillus macroides (E),Pseudomonas fluorescens (Pf), compost, compost + Lysinibacillus macroides (E) and compost + Pseudomonas fluorescens(Pf) along with control on terminal leaf breadth. $(\mathrm{p}<0.05)$. ${ }^{\text {Data }}$ represented as standard deviation of triplicate values.

Treatment of tomato plant with phytohormone secreting Sphingomonas sp exhibited remarkable growth and physiological characteristics such as stimulated plant cell division, enhanced root formation and shoot elongation (49). In our research, maximum number of leaves was observed in plant groups supplemented with compost plus L. macroides by the end of 21 days (Fig. 5). This enhancement could be due to the upregulation of molecules 
secreted by the bioculture that mediate phytostimulation. The transverse section of stem and root of control and the most effective treatment group (compost supplemented with $L$. macroides) was assessed. PGPR supplementation to $S$. lycopersicum increases the number and diameter of cortical cells and vascular tissue which could be attributed to the enhanced nutrient and mineral uptake $(50,51)$. Nutrient deficiency and stress leads to reduced size of vascular bundles affecting the overall plant health $(52,53)$. An increase in pith diameter was noted in the treatment groups whereas size of the cortical cells and xylem vessels remain the same in all groups. Pathogenic effects such as abnormal vasculature or any visual deformities because of PGPR supplementation affecting the morphology and anatomy of $S$. lycopersicum was not observed throughout the treatment period (Fig. 6).

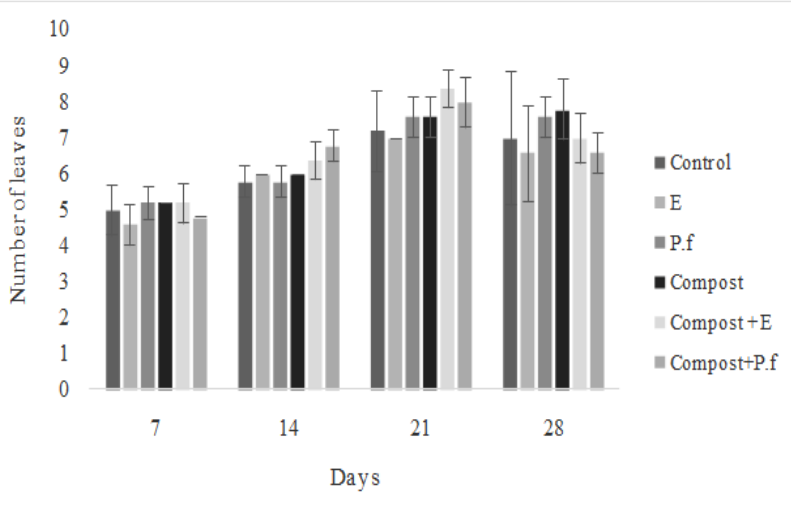

Fig. 5. Effect of culture Lysinibacillus macroides (E), Pseudomonas fluorescens (Pf), compost, compost + Lysinibacillus macroides (E) and compost + Pseudomonas fluorescens (Pf) along with control on number of leaves. ( $>0.05) .{ }^{*}$ Data represented as standard deviation of triplicate values.

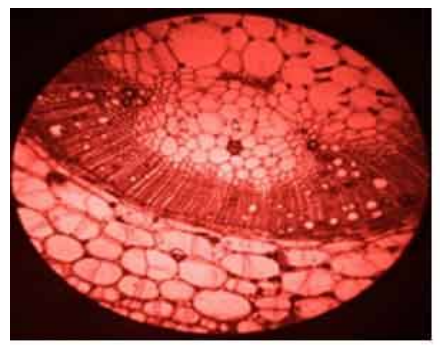

A

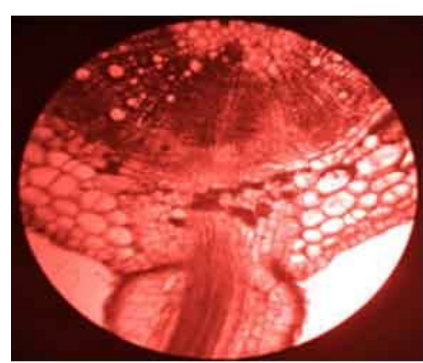

C

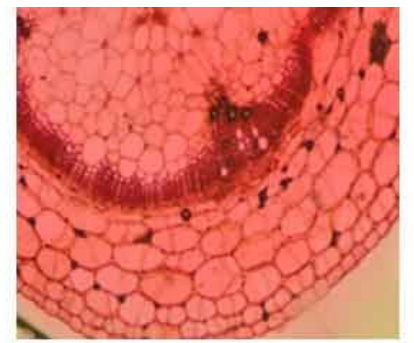

$B$

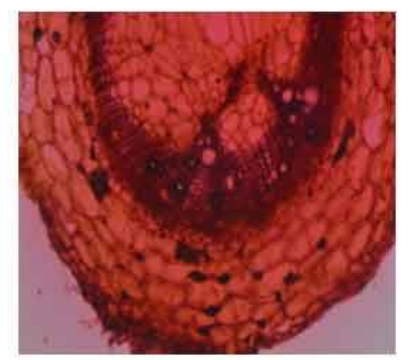

D
Fig. 6. Showing cross sections of transverse sections of stems and roots of control and the treatment group (Compost supplemented with Lysinibacillus macroides) after the 30 day trail. A and B-stem sections of control and treated groups respectively and C, D-root sections of control and treated groups respectively. The specimens were observed at $150 \mathrm{X}$ magnification after staining with safranin.

\section{Estimation of biochemical constituents and phytochemicals}

Efficacy of $L$. macroides on the synthesis of plant pigment chlorophyll, carbohydrate and protein were assessed upon treatment with biofertilizer and compost (Table. 3). Maximum biochemical constituents were observed in compost and biofertilizer supplemented samples $(p<0.05)$. Specific rates of nitrogen supply increase the accumulation of photosynthetic pigments. Higher pigment synthesis could be due to enhanced nitrogen fixation caused by the inoculated PGPR. Nitrogen constitutes the major component of the chlorophyll structure. Bacillus pumilus enhances the synthesis of soluble proteins in soybean plants (54). Combined or sole application of organic manures and biofertilizers increases the yield of the phenolic compounds and phyto components that influence the quality attributes in the tested plant samples. Appropriate usage of $L$. macroides along with compost material increased solubility and bioabsorbtion of nutrients in the current study. Similar results were obtained in Brassica oleracea treated with $P$. fluorescens and humic acid combinations $(55,56)$. Co-inoculation of plant growth promoting rhizobacteria along with farm yard compost enhances the bioaccumulation of nutrients in the mungbean by aiding in nutrient fixation, release, uptake and transportation (57).

Phenolic compounds synthesised by plants contribute for growth and development and involve in various metabolic activities such as plant protection from free radical attack, protection against plant invading pathogens and as signalling messengers (58). In this study, secondary metabolites like polyphenols, flavonoids and tannins were estimated in control and L. macroides supplemented plant samples (Table. 4). Supply of L. macroides alone and L. macroides co-inoculated with compost slot exhibited higher synthesis of flavonoid. No significant differences on flavonoid synthesis were noted between the Pseudomonas and Pseudomonas plus compost supplemented groups. Difference in the synthesis of flavonoid between the treatment groups could be due to the factor associated with the nutrient breakdown and uptake ability of PGPR amended with the compost. Enhanced phenolic content in Serratia marcescens supplemented Piper belte L. was noted (59). Parallel results were observed in chickpea by inoculation of PGPR P. fluorescens and $P$. aeruginosa (60). Enhanced flavonoid concentration was observed in compost and Lysinibacillus macroides co-inoculated compost samples. PGPR stimulates the phenylpropanoid pathway for enhanced polyphenols synthesis thereby contributing to host defense against plant pathogens (61). Induction of polyphenols by compost supplementation along with bacterization using $L$. macroides increased the total phenolic content in the S. lycopersicum. Results of the study suggest that the use of organic fertilizers along with PGPR can enhance the production of plant secondary metabolites. Tannin accumulation is one the primary ways the plant system adopts to avoid stress induced changes. Higher synthesis of tannins and other phenolics are reported for radical quenching activity in Acacia gerrardii supplemented with Bacillus 
subtilis and Mycorrhizal fungi (62). The aromatic oxygen substituted derivatives such as tannins and flavonoids contribute for homeostasis and health maintenance (63). PGPRs influence plant growth, nutrient utilization by producing metabolites such as flavonoids, phenols, saponins and alkaloids that benefit plant growth and stimulation (24).

\section{Antioxidant activity}

Oxidative stress can reduce the nutritional quality of crops. Environmental factors such as air pollution, extensive herbicide/pesticide application, contamination by heavy metal, drought, salinity, injuries can induce oxidative stress in plants. Use of the PGPR can reduce the negative effects caused due to environmental stress by enhancing the antioxidant state (57). PGPR application aids in plant growth by reducing the effect of cold stress and also by activating the enzymes that reduce Reactive Oxygen Species (ROS) (58). In our study, maximum antioxidant activity was observed in plants supplemented with $P$. fluorescens $(76.55 \pm 1.45 \%)$ compared to other treatments by $4^{\text {th }}$ week (Fig. 7). Enhanced DPPH radical quenching activity was noted in $S$. lycopersicum samples treated with compost infused with plant growth promoting bacteria. Mechanism related to enhanced antioxidant activity could be due to the elevation in the expression of antioxidant genes that confer homeostasis in the plant metabolism $(64,65)$. Cucumis sativus infused with Promicro monospora, Burkholdera cepacia, and Acinetobacter calcoaceticus showed enhanced phenol production due to upregulation of antioxidant enzymes (66).

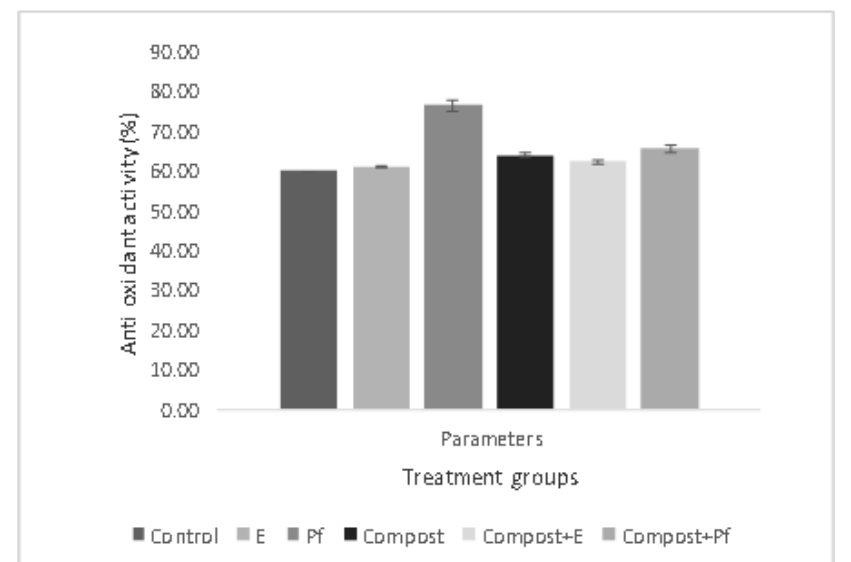

Fig. 7. Antioxidant activity of the culture Lysinibacillus macroides (E),Pseudomonas fluorescens (Pf), compost, compost + Lysinibacillus macroides (E) and compost + Pseudomonas fluorescens (Pf) in comparision to the control. $(\mathrm{p}<0.05)$. *The error bars indicate standard deviation.

\section{Conclusion}

Development of a cost effective, eco-friendly approach for enhancing plant growth is a much needed practice towards developing a productive agricultural ecosystem. Identification and development of functional soil amendments will minimise the usage of chemical fertilisers thereby nourishing the soil with less artificial pollutants. In our study, supplementation of Lysinibacillus macroides infused compost exhibited a promising effect in enhancing the overall plant growth. However, molecular mechanisms that govern the interaction of PGPR with host biomolecules need to be further characterized. Identification and utilisation of novel PGPRs with potential applications in agriculture will increase crop productivity and minimize negative impacts of organic waste.

\section{Acknowledgements}

The authors acknowledge the support received from the Department of Life Sciences and Centre for Research, CHRIST (Deemed to be University) for the financial aid through MRP. (MRPDSC-1936).

Table 2. General characteristics of Lysinibacillus macroides

\begin{tabular}{lll}
\hline Sl. no. & Tests performed & Result \\
\hline 1 & Gram's staining & Gram positive \\
\hline 2 & Shape & Bacilli \\
\hline 3 & Motility (Hanging drop method) & Motile \\
\hline 4. & Indole test & Negative \\
\hline 5. & Methyl red test & Negative \\
\hline 6. & Voges-Proskauer test & Positive \\
\hline 7. & Simmon citrate test & Negative \\
\hline 8. & Catalase test & Positive \\
\hline 9. & Phosphate solubilization & Negative \\
\hline 10. & Ammonia production & Negative \\
\hline 11. & Siderophore production & Negative \\
\hline 12. & Zinc solubilization & Negative \\
\hline 13. & Nitrogen fixation & Positive \\
\hline
\end{tabular}

Table 3. Effect of treatments, Lysinibacillus macroides (E), Pseudomonas fluorescens (Pf), compost, compost + Lysinibacillus macroides (E) and compost + Pseudomonas fluorescens (Pf) along with control on quantitative biochemical parameters chlorophyll, carbohydrate and protein content.

\begin{tabular}{crrrrrr}
\hline Parameters & $\begin{array}{c}\text { Contro } \\
\text { l }\end{array}$ & E & Pf & $\begin{array}{c}\text { Compo } \\
\text { st }\end{array}$ & $\begin{array}{c}\text { Compo } \\
\text { st+E }\end{array}$ & $\begin{array}{c}\text { Compo } \\
\text { st+pf }\end{array}$ \\
\hline Chlorophyll & $1.56 \pm$ & $1.65 \pm$ & $1.56 \pm$ & $1.82 \pm$ & $1.74 \pm$ & $1.75 \pm$ \\
$*(\mathrm{mg} / \mathrm{gm})$ & 0.015 & 0.015 & 0.01 & 0.05 & 0.02 & 0.12 \\
\hline Carbohydrate* & $34.33 \pm$ & $41.58 \pm$ & $25.33 \pm$ & $43.08 \pm$ & $44.25 \pm$ & $27.25 \pm$ \\
(mg/gm) & 0.38 & 1.2 & 2.04 & 0.94 & 0.25 & 1.08 \\
\hline Protein* & $5.68 \pm$ & $7.61 \pm$ & $6.42 \pm$ & $8.63 \pm$ & $7.98 \pm$ & $7.88 \pm$ \\
(mg/gm) & 0.05 & 0.049 & 0.01 & 0.021 & 0.031 & 0.091 \\
\hline
\end{tabular}

Note: All the parameters are significant at $\mathrm{p}<0.05$ and indicated by $*$.

Table 4. Effect of treatments, Lysinibacillus macroides (E), Pseudomonas fluorescens (Pf), compost, compost + Lysinibacillus macroides (E) and compost + Pseudomonas fluorescens (Pf) along with control on quantitative phytochemical parameters chlorophyll, carbohydrate and protein content. *Data represented as standard deviation of triplicate values.

\begin{tabular}{lrrrrrr}
\hline \multicolumn{1}{c}{ Parameters } & $\begin{array}{c}\text { Contr } \\
\text { ol }\end{array}$ & E & Pf & \multicolumn{2}{c}{ Comp Compo Compos } \\
ost & st+E & \multicolumn{1}{c}{ t+pf } \\
\hline Total phenolic & $12.44 \pm$ & $17.43 \pm$ & $14.48 \pm$ & $14.87 \pm$ & $17.58 \pm$ & $13.03 \pm$ \\
content*(mg/gm) & 0.41 & 0.51 & 0.32 & 0.40 & 0.4 & 0.22 \\
\hline Flavonoids*(mg/ & $9.40 \pm$ & $11.43 \pm$ & $9.54 \pm$ & $12.86 \pm$ & $13.04 \pm$ & $12.54 \pm$ \\
gm) & 0.06 & 0.028 & 0.05 & 0.03 & 0.05 & 0.06 \\
\hline Tannins* & $8.01 \pm$ & $15.78 \pm$ & $11.30 \pm$ & $10.10 \pm$ & $13.62 \pm$ & $9.04 \pm$ \\
(mg/gm) & 0.01 & 0.07 & 0.03 & 0.03 & 0.04 & 0.13 \\
\hline
\end{tabular}

Note:: All the parameters are significant at $\mathrm{p}<0.05$ and indicated by *. 


\section{Authors' contributions}

JS was involved in the experimental design, data collection. RA and BN were involved in data analysis and drafted this manuscript. PKA conceptualized the idea, involved in funding and revised this manuscript. All authors read and approved the manuscript.

\section{Conflict of interests}

The authors declare no conflicts of interest.

\section{References}

1. Ajmal M, Iqra AH, Saeed R, Akhtar A, Tahir M, Zain MM, Ayub A et al. Biofertilizer as an Alternative for Chemical Fertilizers. JAAS. 2018;7(1):1-7.

2. Singh R, Singh GS. Traditional agriculture: A climate-smart approach for sustainable food production. Energy Ecol Environ. 2017;2:296-316. https://doi.org/10.1007/s40974-017-0074-7

3. Ibiene AA, Agogbua JU, Oknonko IO, Nwachi GN. Plant growth promoting rhizobacteria (PGPR) as biofertilizer: Effect on growth of Lycopersicum esculentum. J Am Sci. 2012;8(2):318-24.

4. Gerszberg A, Hnatuszko KK, Kowalczyk T. Tomato (Solanum lycopersicum L.) in the service of biotechnology. Plant Cell Tiss Organ Cult. 2015;120:881-902. https://doi.org/10.1007/s11240-0140664-4

5. Alam S, Kumar SR. Comparative study on effect of chemical and biofertilizer on growth development and yield production of paddy crop (Oryza sativa). Int J Sci Res. 2014;3(9):411-14.

6. Vejan P, Abdullah R, Khadiran T, Ismail S, Nasrulhaq BA. Role of Plant Growth Promoting Rhizobacteria in Agricultural Sustainability-A Review. Molecules. 2016;29(21):573. https://doi.org/ 10.3390/molecules2105057

7. Hussein MS, Hendawy SF, Sherbeny SE. Comparative effect of organic fertilizers on growth and chemical constituents of Plantagoovata Plant. Caspian J Appl Sci Res. 2012;1(16):13-19.

8. Thomson AJ, Giannopoulos G, Pretty J, Baggs EM, Richardson DJ. Biological sources and sinks of nitrous oxide and strategies to mitigate emissions. Philos Trans R Soc Lond B Biol Sci. 2012; 5(367):1157-68. https://doi.org/10.1098/rstb.2011.0415

9. Glick BR, Penrose DM, Li J. A model for the lowering of plant ethylene concentrations by plant growth promoting bacteria. J Theor Biol. 1998;190:63-68. https://doi.org/10.1006/jtbi.1997.0532

10. Iqbal U, Jamil N, Ali I, Hasnain S. Effect of zincphosphate-solubilizing bacterial strains on growth of Vigna radiata. Ann Microbiol. 2010;60(2):1869-2044. https://doi.org/10.1007/s13213-0100033-4

11. Kang S M, Joo GJ, Hamayun M, Na C I, Shin D, Kim HY, Hong JK, Lee IJ et al. Gibberellin production and phosphate solubilization by newly isolated strains of Acinetobacter calcoaceticus and its effect on plant growth. Biotechnol Lett. 2009;31(2):277-81.https:// doi.org/ 10.1007/s10529-008-9867-2

12. Siddikee MA, Chauhan PS, Anandham R, Han GH, Sa T. Isolation characterization and use for plant growth promotion under salt stress of ACC deaminase-producing halotolerant bacteria derived from coastal soil. J Microbiol Biotechnol. 2010;20(11):157784. https://doi.org/10.4014/jmb.1007.07011

13. Swain MR, Ray RC, Nautiyal CS. Biocontrol efficacy of Bacillus subtilis strains isolated from cow dung against postharvest yam (Dioscorea rotundata L.) pathogens. Curr Microbiol. 2008; 57(5):407-11 https://doi.org/ doi: 10.1007/s00284-008-9213-x.

14. Persello CF, Nussaume L, Robaglia C. Tales from the underground: Molecular plant-rhizobacteria interactions. Plant Cell Environ. 2003;26:189-99. https://doi.org/10.1046/j.13653040.2003.00956.x

15. Adeniyan ON, Ojo A, Akinbode OA, Adediran JA. Comparative study of different organic manures and NPK fertilizer for improvement of soil chemical properties and dry matter yield of maize in two different soils. J Soil Sci Manage. 2011;2:9-13.
16. Akinrinlola RJ, Yuen GY, Drijber RA, Adesemoye AO. Evaluation of Bacillus Strains for Plant Growth Promotion and Predictability of Efficacy by In Vitro Physiological Traits. Int.J.Microbiol. 2018;2018(53):1-11. https://doi.org/10.1155/2018/5686874

17. Sunera, Amna, Saqib S, Uddin S, Zaman W, Ullah F et al. Characterization and phytostimulatory activity of bacteria isolated from tomato (Lycopersicon esculentum Mill.) rhizosphere. Microb Pathog. 2020;140:103966. https://doi.org/10.1016/ j.micpath.2020.103966

18. Franchi E, Rolli E, Marasco R, Agazzi G, Borin S, Cosmina P, Petruzzelli $\mathrm{G}$ et al. Phytoremediation of a multi contaminated soil mercury and arsenic phytoextraction assisted by mobilizing agent and plant growth promoting bacteria. JSSS. 2017; 17(5):1224-36. https://doi.org/10.1007/s11368-015-1346-5

19. Liu K, Garrett C, Fadamiro H, Kloepper JW. Antagonism of black rot in cabbage by mixtures of plant growth-promoting rhizobacteria (PGPR). BioControl. 2016;61(5):605-13. https://doi.org/ 10.1007/s10526-016-9742-3

20. Hameed A,Yeh M, Hsieh Y. Diversity and functional characteriz ation of bacterial endophytes dwelling in various rice (Oryza sativa L.) tissues and their seed-borne dissemination into rhizosphere under gnotobiotic P-stress. Plant Soil. 2015; 394:177-97. https://doi.org/10.1007/s11104-015-2506-5

21. Bano SA, Iqbal SM. Biological Nitrogen Fixation to Improve Plant Growth and Productivity. Int J Agric Innov Res. 2017;4:23191473.

22. Shah R, Chaudhari K, Patel P, Natarajan A, Ramar K. Isolation, characterization, and optimization of indole acetic acid-producing Providencia species (7MM11) and their effect on tomato ( $L y$ copersicon esculentum) seedlings. Biocatal Agric Biotechnol 2020;28:101732. https://doi.org/10.1016/j.bcab.2020.101732

23. Saqib S, Zaman W, Ayaz A, Habib S, Bahadur S, Hussain S et al. Postharvest disease inhibition in fruit by synthesis and characterization of chitosan iron oxide nanoparticles. Biocatal Agric Biotechnol. 2020;28:101729. https://doi.org/10.1016/ j.bcab.2020.101729

24. Sharma RR, Singh D, Singh R. Biological control of postharvest diseases of fruits and vegetables by microbial antagonists: A review. Biol Control. 2009;50(3):205-21. https://doi.org/10.1016/j. biocontrol.2009.05.001

25. Kour D, Rana KL, Yadav AN, Yadav N, Kumar M, Kumar V et al. Microbial biofertilizers: Bioresources and eco-friendly technologies for agricultural and environmental sustainability. Biocatal Agric Biotechnol. 2020;23(2019):101487. https://doi.org/10.1016/ j.bcab.2019.101487

26. Mikanová O, Nováková J. Evaluation of the P-solubilizing activity of soil microorganisms and its sensitivity to soluble phosphate. Plant Soil Environ. 2002;48(9):397-400. https://doi.org 10.17221/4386-PSE

27. Mumtaz MZ, Ahmad, Jamil M, Hussain T. Zinc solubilizing Bacillus spp. potential candidates for biofortification in maize. Microbiol Res. 2017;202:51-60. https://doi.org/10.1016/ j.micres.2017.06.001

28. Kumar A, Devi S, Patils, Payal C, Neg IS. Isolation screening and characterization of bacteria from rhizospericsoils for different plant growth promotion (PGP) activities: an in vitro study. Recent Res Sci Technol. 2012;4(1):01-05.

29. Yeole RD, Dube HC 2000. Siderophore mediated antibiosis of rhizobacterial fluorescent Pseudomonas against certain soil borne fungal plant pathogens. J Mycol Plant Pathol. 2000;30(3):335-38.

30. Kimura M. A simple method for estimating evolutionary rate of base substitutions through comparative studies of nucleotide sequences. J Mol Evol. 1980;16(2):111-20. https://doi.org/10.1007/ BF01731581

31. Kumar S, Stecher G, Tamura K. MEGA7: Molecular Evolutionary Genetics Analysis version 7.0 for bigger datasets. Mol Biol Evol. 2016;33(7):1870-74. https://doi.org/10.1093/molbev/msw054

32. Platt AR, Woodhall RW, George AL Jr. Improved DNA sequencing quality and efficiency using an optimized fast cycle sequencing protocol. Biotechniques. 2007;43(1):58-60. https://doi.org/ 10.2144/000112499

33. Ashrafuzzaman M, Hossen FA, Ismail MR, Hoque A, Islam MZ, Shahidullah SM, Meon S et al. Efficiency of plant growthpromot- 
ing rhizobacteria (PGPR) for the enhancement of rice growth. Afr J Biotechnol. 2009;8(7):1247-52.

34. Alberola C, Lichtfouse E, Navarrete $M$, Debaeke $P$, Souchère V. Plant growth promoting bacteria as biofertilizer. Agron Sustain Dev. 2006;26:143-50. https://doi.org/10.1051/agro:2006007

35. Kamble PN, Giri SP, Mane RS, Tiwana A. Estimation of chlorophyll content in young and adult leaves of some selected plants. Univers J Environ Res Technol. 2011;5(6):306-10.

36. Bradford MM.A rapid and sensitive method for the quantitation of microgram quantities of protein utilizing the principle of protein-dye binding. Anal Biochem. 1976;72(1-2):248-54. https:/ doi.org/10.1016/0003-2697(76)90527-3

37. DuBois M, Smith F, Rebers PA, Gilles KA, Hamilton JK. Colorimetric method for determination of sugars and related substances. Anal Chem. 2005;28(3):350-56. https://doi.org/10.1021/ ac60111a017

38. Blois MS. Antioxidant determination by the use of a stable free radicle. Nature. 1958;181(4617):1199-1200. https://doi.org/ 10.1038/1811199a0

39. Singleton VL, Orthofer R, Lamuela RM. Analysis of total phenols and other oxidation substrates and antioxidants by means of folin-ciocalteu reagent. Methods Enzymol. 1998;299(1998):152-78. https://doi.org/10.1016/S0076-6879(99)99017-1

40. Chang C, Yang MH, Wen HM, Chern JC. Estimation of total flavonoid content in propolis by two complementary colorimetric methods. Journal of Food Drug Anal. 2002;10(3):178-82. https://doi.org/10.38212/2224-6614.2748

41. Noorieh B, Arzanesh MH, Mahlegha G, Maryam S. The effect of plant growth promoting rhizobacteria on growth parameters, antioxidant enzymes and microelements of canola under salt stress. J Appl Environ Biol Sci. 2013;3:17-27.

42. Anna LB, Alessandra S, Claudia E, Paola C, Maddalena DG. In vitro and in vivo inoculation of four endophytic bacteria on Lycopersicon esculentum. New Biotechnol. 2013;30:666-74. https:/ doi.org/10.1016/j.nbt.2013.01.001

43. Jay PV, Janardan Y, Kavindra NT, Ashok K. Effect of indigenous Mesorhizobium spp. and plant growth promoting rhizobacteria on yields and nutrients uptake of chickpea (Cicer arietinum L.) under sustainable agriculture. Ecol Eng. 2013;51:282-86. https:// doi.org/10.1016/j.ecoleng.2012.12.022

44. Julieta C, Lorena RC, Lucas G. Sosa A, Tamara BP, Erika B. Plant growth promoting rhizobacteria improve the antioxidant status in Mentha piperita grown under drought stress leading to an enhancement of plant growth and total phenolic content,IND CROP PROD. 2019;139:111553. https://doi.org/10.1016/ j.indcrop.2019.111553

45. Jha Y and Subramanian RB. PGPR regulate caspase-like activity, programmed cell death and antioxidant enzyme activity in paddy under salinity. Physiology and molecular biology of plants. Int J Funct Plant Biol. 2014;20(2):201-07. https://doi.org/ 10.1007/s12298-014-0224-8

46. Ahmad R, Arshad M, Khalid A, Zahir A. Effectiveness of organic bio fertilizer supplemented with chemical fertilizers for improving soil water retention aggregate stability growth and nutrient uptake of maize (Zea mays L.). J Sus Agri. 2008;31(4):57-77. https://doi.org/10.1300/J064v31n04_05

47. Ipsita D, Singh AP. Effect of organic manures and PGPR on Nutrient content and uptake of munbean. Unique Res J Chem. 2014;2:9-12.

48. Naveed M, Hussain MB, Zahir ZA, Mitter B, Sessitsch A. Drought stress amelioration in wheat through inoculation with Burkholderia phytofirmans strain PsJN. Plant Growth Regul. 2014;73(2):121-31._https://doi.org/10.1007/s10725-013-9874-8

49. Khan AL, Waqas M, Kang SM. Bacterial endophyte Sphingomonas sp. LK11 produces gibberellins and IAA and promotes tomato plant growth. J Microbiol. 2014;52(8):689-95. https://doi.org/ 10.1007/s12275-014-4002-7

50. Batistão AC, Yamashita OM, Silva IV, Araújo CF, Lavezo A. Anatomical changes on the stem and leaves of Solanum lycopersicum caused by diferente concentrations of picloram $+2.4-\mathrm{D}$ in two different types of soil. Planta Daninha. 2018;36:1-12. https:// doi.org/10.1590/s0100-83582018360100106
51. Backer R, Rokem JS, Ilangumaran G, Lamont J, Praslickova D, Ricci E, Subramanian S, Smith DL et al. Plant Growth-Promoting Rhizobacteria: Context, Mechanisms of Action, and Roadmap to Commercialization of Biostimulants for Sustainable Agriculture. Front. Plant Sci. 2018;9:1473. https://doi.org/10.3389/ fpls.2018.01473

52. Alsafari SA, Galal HK, Bafeel SO. Growth and anatomy of the tomato (Solanum lycopersicum Mill.) cultivars Marmande and Oria under salinity stress. Pak J Bot. 2019;51(4):1199-1207. https:// doi.org/10.30848/PJB2019-4(16)

53. Agami R, Medani R, Abd Mola I, Taha R. Exogenous application with plant growth promoting rhizobacteria (PGPR) or proline induces stress tolerance in basil plants (Ocimum basilicum L.) exposed to water stress. Int J Environ Agri Res. 2016;2:78

54. Stefan M, Munteanu N, Stoleru V, Mihasan M. Effects of inoculation with plant growth promoting rhizobacteria on photosynthesis, antioxidant status and yield of runner bean. Rom Biotechnol Lett. 2013;18:8132-43.

55. Sattari R, Nasab M, PahlavanY, Bozorg-Amirkalaee M. Effects of humic acid and plant growth-promoting rhizobacteria (PGPR) on induced resistance of canola to Brevicoryne brassicae L. Bul Entomol Res. 2018;109(4):479-89. https://doi.org/10.1017/ S0007485318000779

56. Sharafzadeh S, Ordookhani K. Organic and bio fertilizers as a good substitute for inorganic fertilizers in medicinal plants farming. Aus J Basic Appl Sci. 2011;5:1330-1333.

57. Cappellari R, Santoro MV, Nievas F, Giordano W, Banchio E. In crease of secondary metabolite content in marigold by inoculation with plant growth-promoting rhizobacteria. Appl Soil Ecol 2013;70:16-22. https://doi.org/10.1016/j.apsoil.2013.04.001

58. SinghV, Vivekananda M,Krishi P, Sansthan A, Verma R. Integrated effect of bio-organics with chemical fertilizer on growth yield and quality of cabbage (Brassica oleracea var. capitata) Indian J Agri Res. 2014;84(8):914-19.

59. Lavania M, Chauhan PS, Chauhan SVS, Singh HB, Nautiyal CH. Induction of plant defense enzymes and phenolics by treatment with plant growth promoting rhizobacteria Serratia marcescen NBRI1213. Curr Microbiol. 2006;52:363-68. https://doi.org/ 10.1007/s00284-005-5578-2

60. Singh UP, Sarma BK, Singh DP. Effect of plant growth-promoting rhizobacteria and culture filtrate of Sclerotium rolfsii on phenolic and salicylic acidcontents in Chickpea (Cicer arietinum). Curr Microbiol. 2003;46:131-40. https://doi.org/10.1007/s00284-002 3834-2

61. Van Peer R, Nieman GJ, Schippers B. Induced resistance and phytoalexin accumulation in biological control of Fusarium wilt of carnation by Pseudomonas WCS417r. Phytopathology. 1991; 81:728-34. https://doi.org/10.1094/Phyto-81-728

62. Hashem A, AbdAllah EF, Alqarawi AA, Al-Huqail AA, Shah MA Induction of Osmoregulation and Modulation of Salt Stress in Acacia gerrardii Benth. by Arbuscular Mycorrhizal Fungi and Bacillus subtilis (BERA 71). BioMed Res Int. 2016;2016(1):1-11. https://doi.org/10.1155/2016/6294098

63. Swamy MK, Akhtar MS. Plant Soil and Microbes 2nd ed. Switzer land: Springer. 2016. https://doi.org/10.1007/978-3-319-29573-2

64. Khanna K, Sharma A, Ohri P, Bhardwaj R, Abd Allah EF, Hashem A, Ahmad P et al. Impact of Plant Growth Promoting Rhizobacteria in the Orchestration of Lycopersicon esculentum Mill. Resistance to Plant Parasitic Nematodes: A Metabolomic Approach to Evaluate Defense Responses Under Field Conditions. Biomolecules. 2019;9(11):676. https://doi.org/10.3390/biom9110676

65. Asghar M, Habib S, Zaman W, Hussain S, Ali H, Saqib S. Synthesis and characterization of microbial mediated cadmium oxide nanoparticles. Microsc Res Tech. 2020;83(12):1574-84. https:// doi.org/10.1002/jemt.23553

66. Sang-Mo K, Abdul LK, Muhammad W, Young-Hyun Y, Jin-Ho K Jong-Guk K, Muhammad H, In-Jung L et al. Plant growth-promoting rhizobacteria reduce adverse effects of salinity and osmotic stress by regulating phytohormones and antioxidants in $\mathrm{Cu}$ cumis sativus, J Plant Interact. 2014;9(1):673-82. https://doi.org/ 10.1080/17429145.2014.894587 